Araştırma Makalesi

(Research Article)

Yaşar Tuncer KAVUT

A. Esen ÇELEN

Gülcan DEMIROĞLU TOPÇU

Behçet KIR

Ege Üniversitesi, Ziraat Fakültesi, Tarla Bitkileri Bölümü, 35100 İzmir/Türkiye

e-posta: tunver.kavut@ege.edu.tr

Anahtar Sözcükler:

Yonca genotipleri, yeşil ot verimi, kuru madde verimi

Key Words:

Alfalfa genotypes, fresh harbage yield, dry matter yield
Ege Üniv. Ziraat Fak. Derg., 2014, 51 (1): 23-29

ISSN $1018-8851$

\section{Bazı Yonca (Medicago sativa L.) Genotiplerinin Farklı Lokasyonlardaki Verim ve Verim Özellikleri Üzerinde Bir Araştırma'}

\author{
An Investigation on Yield and Some Yield Characteristics of \\ Different Alfalfa Genotypes Grown in Different Locations
}

${ }^{1} \mathrm{Bu}$ araştırma, 2007-ZRF-040 no'lu Ege Üniversitesi Bilimsel Araştırma Projesi
verilerinden yararlanılarak düzenlenmiştir.

Alınış (Received):09.05.2013

Kabul tarihi (Accepted): 11.09.2013

\begin{abstract}
This study was conducted in the experimental fields of Ege University in Bornova and Ödemiş for two years during the 2006 and 2007. In the trial herbage yield and some yield characteristics of some alfalfa (Medicago sativa $\mathrm{L}$.) genotypes (TT-2008, TT-2009, Pioneer-5683 ve Elçi) under Mediterranean climatic conditions were determined. Results indicated that TT-2008 and P$5683 \mathrm{cv}$. had better performance than other genotypes in terms of yields of herbage and dry matter. The yields in Odemis location, which was sandy-loam soil texture, were higher than in Bornova location.
\end{abstract}

\section{GíRiş}

Ülkemizdeki yaklaşık 11.2 milyon BBHB hayvan varlığının yaşam paylarının karşılanması için gereksinim duyulan yıllık toplam kaliteli kaba yem ihtiyacı 57 milyon ton'dur. Bu ihtiyacın giderilmesinde yararlanılan kaynaklardan yılda 33 milyon ton kadar bir üretim elde edilmekte ve geriye yaklaşık 24 milyon tonluk kaliteli kaba yem açığı ortaya çıkmaktadır (Alçiçek vd., 2010). 14.6 milyon ha'lık mera alanımızın (TUIK, 2011) verim potansiyelleri, yıllardır süre gelen ağır otlatma ve amenajman ilkelerine uyulmaması sonucu giderek azalmıştır (Tükel ve Hatipoğlu, 1994). Ülkemizdeki yembitkileri ekiliş alanı, mısır ekim alanlarının da ilavesi ile 1.508.292 ha olup, bunun 558.553 ha'lık kısmında yonca tarımı yapılmaktadır (TUIK, 2011). Mevcut yem açığının giderilmesinde yem üretim alanlarının genişletilmesi yanında kullanılan çeşitlerin de verim potansiyellerinin yüksek olması gerekmektedir. Bu araştırma, Ege bölgesinin farklı toprak yapılarına sahip olan lokasyonlarda (Bornova ve Ödemiş) yetiştirilecek 
bazı yeni yonca genotiplerinin bazı verim ve morfolojik özellikleri ile bölgeye adaptasyon yeterliliklerinin ortaya konulması amacıyla yürütülmüştür.

Chamblee ve Warren (1990), iki yıllık deneme sonuçlarına göre yonca'da bitki boyunun 29.0-60.5 $\mathrm{cm}$ olduğunu bildirmişlerdir. Sharma ve Sharma (1993), Hindistan koşullarında 3 yıl süre ile yürüttükleri çalışmalarında, ele aldıkları yonca çeşitlerinin (T9, Anad ve ss627) yeşil ot verimlerinin ortalama olarak, sırasıyla 7308, 7645 ve $7942 \mathrm{~kg} / \mathrm{da}$ olduğunu ifade etmişlerdir. Loges and Taube (1995), Kiel/Almanya koşullarında Daisy yonca çeşidi ile sürdürdükleri çalışmalarında kuru madde veriminin $1587 \mathrm{~kg} / \mathrm{da}$ olduğunu bildirmişlerdir. Aka ve Avcıoğlu (1999), 1998 yetiştirme döneminde İzmir ili Selçuk ilçesinde yürüttükleri çalışmada, ana sap çapının 2.24-2.74 mm, kuru madde oranın \%22,5-24,6 ve kuru madde veriminin de $1153-1473 \mathrm{~kg} / \mathrm{da}$ arasında değiştiğini ifade etmişlerdir. Şeker vd. (2003), Kayseri ve Bilensoy80 yonca çeşitleri ile yürüttükleri çalışmalarında, yoncada bitki boyunun 76.50-84.90 cm, ana sap çapının 3.70-4.00 mm ve sap sayının da 12.30-16.80 adet arasında değiştiğini bildirmişlerdir. Pecetti et al. (1999), inceledikleri yonca çeşitlerinin ana sap uzunluğu bakımından istatistiki olarak önemli farklııklar içerdiklerini saptamışlardır. Kavut ve Soya (2004), Bornova-Izmir koşullarında 4 farklı yonca çeşidi ile yapmış oldukları çalışmalarında, bitkide ana sap sayısının 12.14-12.41 adet, kuru madde oranının $\% 22.15-23.13$ ve kuru madde veriminin de 1422-1624 $\mathrm{kg} / \mathrm{da}$ arasında değiştiğini bildirmişlerdir. Ayaz ve Kızılşimşek (2010), tohumluk materyali olarak Elçi yoncası çeşidini kullandıkları ve Kahramanmaraş koşullarında sürdürdükleri çalışmalarında, yeşil ot veriminin $9289 \mathrm{~kg} /$ da olduğunu bildirmişlerdir. Töngel ve Ayan (2010), Samsun koşullarında 19 farklı yonca çeşidi ile yürüttükleri çalışmalarında, bitki boyunun $66.85-83.00 \mathrm{~cm}$ ve ana sap çapının 2.93-3.27 mm arasında değiştiğini ifade etmişlerdir. Turan ve Çelen (2010), 5 farklı yonca çeşidi ile Van koşullarında yürüttükleri çalışmalarında, bitki boyunun 71.4-87.7 $\mathrm{cm}$, dal sayısının 29.3-37.3 adet, yeşil ot veriminin $2254-3374 \mathrm{~kg} / \mathrm{da}$ ve kuru madde veriminin de 758 $1150 \mathrm{~kg} / \mathrm{da}$ arasında değiştiğini bildirmişlerdir. Yılmaz ve Albayrak (2011), 5 farklı yonca çeşidi ile Isparta koşullarında yürüttükleri çalışmlarında, ana sap uzunluğunun $67.74-72.44 \mathrm{~cm}$, ana sap çapının 17.61$19.02 \mathrm{~mm}$, sap sayısının 17.61-19.02 adet ve yeşil ot veriminin de $8181-10247 \mathrm{~kg} / \mathrm{da}$ arasında değiştiğini ifade etmişlerdir.Çınar ve Hatipoğlu (2012), Magnum-V yonca çeşidi ile Adana koşullarında yapmış oldukları çalışmada, ortalama bitki boyunun $65.7 \mathrm{~cm}$, yeşil ot veriminin $4443 \mathrm{~kg} / \mathrm{da}$ ve kuru madde veriminin de $1039 \mathrm{~kg} / \mathrm{da}$ olduğunu bildirmişlerdir. Yüksel ve Balabanlı (2012), Isparta koşullarında Altiva yonca çeşidi ile yapmış oldukları çalışmalarında ortalama bitki boyunun $85.70 \mathrm{~cm}$ ve yeşil ot veriminin de 8670 $\mathrm{kg} / \mathrm{da}$ olduğunu ifade etmişlerdir.

\section{MATERYAL ve YÖNTEM}

Araştırma; 2006 ve 2007 yıllarında, Ege Üniversitesi Ziraat Fakültesi Tarla Bitkileri Bölümü ve Ödemiş Meslek Yüksekokulu'nun deneme tarlalarında yürütülmüştür.

Denemelerin yürütüldüğü lokasyonlara ait bazı iklim verileri ile bazı toprak özellikleri Çizelge 1 . ve 2.'de özetlenmiştir (Anonim 2006a ve 2006b). Toprak özellikleri incelendiğinde, toprak bünyesi bakımından Ödemiş lokasyonunun (kumlu-tınlı), Bornova lokasyonuna (killi-tınlı) oranla daha hafif bir toprak bünyesine sahip olduğu ifade edilebilmektedir.

Araştırma yerlerinin gerek iklim ve gerekse toprak özellikleri, yonca tarımında kısıtlayıcı bir etki göstermemektedir.

Çizelge 1. Deneme alanı topraklarının bazı fiziksel ve kimyasal özellikleri

Table 1. Some physical and chemical characteristics of experimental areas' soils

\begin{tabular}{lcclcc}
\hline Toprak Özellikleri & Bornova & Ödemiş & Toprak Özellikleri & Bornova & Ödemiş \\
\hline Kum (\%) & 24.72 & 68.72 & Organik Madde (\%) & 1.13 & 1.58 \\
Mil (\%) & 42.72 & 24.00 & CaCO3 (\%) & 21.52 & 1.44 \\
Kil (\%) & 32.56 & 7.28 & $\mathbf{N}(\%)$ & 0.11 & 0.16 \\
pH & 7.80 & 7.28 & $\mathbf{P}(\mathbf{p p m})$ & 40.52 & 20.50 \\
Tuz (\%) & 0.095 & 0.03 & $\mathbf{K}(\mathbf{p p m})$ & 400 & 110 \\
\hline
\end{tabular}


Çizelge 2. Araştırma yerlerine ait bazı meteorolojik veriler Table 2. Some meteorological data for experimental areas

\begin{tabular}{|c|c|c|c|c|c|c|}
\hline \multicolumn{7}{|c|}{ ORTALAMA SICAKLIK ( $\left.{ }^{\circ} \mathrm{C}\right)$} \\
\hline & \multicolumn{2}{|c|}{2006} & \multicolumn{2}{|c|}{2007} & \multicolumn{2}{|c|}{ Çok Yıllık Ort. } \\
\hline Aylar & Bornova & Ödemiş & Bornova & Ödemiş & Bornova & Ödemiş \\
\hline Nisan & 16.8 & 16.2 & 16.2 & 14.7 & 15.1 & 14.6 \\
\hline Mayıs & 21.0 & 20.5 & 22.4 & 21.7 & 20.3 & 19.9 \\
\hline Haziran & 26.2 & 25.4 & 27.5 & 27.1 & 25.5 & 25.0 \\
\hline Temmuz & 28.5 & 27.9 & 30.1 & 29.5 & 28.0 & 27.5 \\
\hline Ağustos & 29.2 & 28.4 & 29.2 & 28.8 & 27.3 & 26.6 \\
\hline Eylül & 23.5 & 22.8 & 24.4 & 23.0 & 22.9 & 22.1 \\
\hline Ekim & 18.3 & 17.9 & 19.7 & 18.3 & 18.0 & 16.9 \\
\hline Kasım & 11.4 & 10.2 & 12.0 & 17.9 & 12.8 & 11.4 \\
\hline ORTALAMA & 21.9 & 21.2 & 22.7 & 22.6 & 21.2 & 20.5 \\
\hline \multicolumn{7}{|c|}{ TOPLAM YAĞIŞ (mm) } \\
\hline & \multicolumn{2}{|c|}{2006} & \multicolumn{2}{|c|}{2007} & \multicolumn{2}{|c|}{ Çok Yıllık Ort. } \\
\hline Aylar & Bornova & Ödemiş & Bornova & Ödemiş & Bornova & Ödemiş \\
\hline Nisan & 27.0 & 14.1 & 19.3 & 35.4 & 49.5 & 54.8 \\
\hline Mayıs & 0.0 & 21.4 & 44.1 & 31.5 & 30.6 & 26.6 \\
\hline Haziran & 19.2 & 6.2 & 0.3 & 6.8 & 9.0 & 10.4 \\
\hline Temmuz & 0.0 & 22.0 & 0.0 & 0.0 & 3.2 & 5.1 \\
\hline Ağustos & 0.0 & 0.0 & 0.0 & 0.0 & 1.6 & 1.6 \\
\hline Eylül & 133.5 & 66.9 & 0.0 & 7.0 & 16.1 & 14.8 \\
\hline Ekim & 88.6 & 77.0 & 107.7 & 74.5 & 37.3 & 34.1 \\
\hline Kasım & 46.7 & 65.1 & 138.5 & 138.5 & 95.8 & 85.5 \\
\hline TOPLAM & 315.0 & 272.7 & 309.9 & 293.7 & 243.1 & 232.9 \\
\hline
\end{tabular}

Denemelerde, tohumluk materyali olarak Pioneer5683, Elçi, TT-2008 ve TT-2009 genotipleri incelenmiştir. Her bir lokasyondaki denemeler 4 tekerrürlü ve parsel boyutlarl; $2 \mathrm{~m} \times 4 \mathrm{~m}=8 \mathrm{~m}^{2}$ olarak tutulmuştur. Ekim normu $2 \mathrm{~kg} / \mathrm{da}$ olarak tutulmuş ve sıra arası mesafe $20 \mathrm{~cm}$ olarak ayarlanmıştır.

Ekimler, Bornova'da 17 Ekim 2005, Ödemiş lokasyonunda ise 19 Ekim 2005 tarihinde yapılmıştır. Gübreleme işlemleri toprak analizleri yapıldıktan sonra gerçekleştirilmiş ve bitkinin erken dönemdeki azot gereksinimlerini karşılamak için $3 \mathrm{~kg} / \mathrm{da}$ saf azot içeren gübre (Amonyum nitrat) ve ayrıca $10 \mathrm{~kg} / \mathrm{da}$ fosforlu gübre (Triple Süper Fosfat) uygulanmıştır. Fosforlu gübreleme uygulaması 2. yılda her iki lokasyonda da tekrarlanmıştır. Yabancı bitkilerle savaşımda herbisit kullanılmamış, sadece erken fide gelişim döneminde bitkilerin yabancı otlarla olan rekabeti zayıf olduğundan, bağ bıçakları ile mekanik olarak savaşım yapılmıştır. Her iki lokasyonda, ilk yetiştirme yılında zararlılar ile savaşıma gerek duyulmamış, ikinci yıl sadece Bornova lokasyonunda yonca hortumlu böceği (Hypera variabilis)'ne karşı savaşımda insektisit kullanılmıştır.

Çizelge 3. Yonca genotiplerinin hasat tarihleri

Table 3. Harvesting dates for alfalfa cultivars

\begin{tabular}{|c|c|c|c|c|c|c|c|c|}
\hline & \multicolumn{8}{|c|}{ Bornova Lokasyonu 1. Yıl (2006) } \\
\hline & 1. & 2. & 3. & 4. & 5. & 6. & 7. & 8. \\
\hline Tा-2008 & $10 / 04$ & $10 / 05$ & $10 / 06$ & $07 / 07$ & $07 / 08$ & $14 / 09$ & - & - \\
\hline ТТ-2009 & $14 / 04$ & $17 / 05$ & $16 / 06$ & $14 / 07$ & $14 / 08$ & $22 / 09$ & - & - \\
\hline P-5683 & $12 / 04$ & $12 / 05$ & 09/06 & 04/07 & $07 / 08$ & $11 / / 09$ & - & - \\
\hline \multirow[t]{2}{*}{ Elçi } & $14 / 04$ & $17 / 05$ & $19 / 06$ & $17 / 07$ & $18 / 08$ & $25 / 09$ & - & - \\
\hline & \multicolumn{8}{|c|}{ Bornova Lokasyonu 2. Yıl (2007) } \\
\hline ТТ-2008 & $05 / 04$ & $02 / 05$ & $25 / 05$ & $19 / 06$ & $17 / 07$ & $17 / 08$ & $01 / 10$ & $08 / 11$ \\
\hline ТT-2009 & $10 / 04$ & $10 / 05$ & $07 / 06$ & $29 / 06$ & $25 / 07$ & $20 / 08$ & $03 / 10$ & $12 / 11$ \\
\hline P-5683 & 07/04 & $04 / 05$ & $28 / 05$ & $21 / 06$ & $16 / 07$ & $20 / 08$ & $01 / 10$ & 09/11 \\
\hline \multirow[t]{2}{*}{ Elçi } & $12 / 04$ & $15 / 05$ & $14 / 06$ & $13 / 07$ & $09 / 08$ & $04 / 09$ & $19 / 10$ & $28 / 11$ \\
\hline & \multicolumn{8}{|c|}{ Ödemiş Lokasyonu 1. YıI (2006) } \\
\hline ТТ-2008 & $11 / 04$ & $15 / 05$ & $16 / 06$ & $13 / 07$ & $10 / 08$ & $13 / 09$ & - & - \\
\hline ТТ-2009 & $14 / 04$ & $22 / 05$ & $23 / 06$ & $19 / 07$ & $15 / 08$ & $19 / 09$ & - & - \\
\hline P-5683 & $12 / 04$ & $16 / 05$ & $16 / 06$ & $11 / 07$ & $04 / 08$ & 06/09 & - & - \\
\hline \multirow[t]{2}{*}{ Elçi } & $18 / 04$ & $26 / 05$ & $30 / 06$ & $28 / 07$ & $25 / 08$ & $29 / 09$ & - & - \\
\hline & \multicolumn{8}{|c|}{ Ödemiş Lokasyonu 2. YıI (2007) } \\
\hline ТТ-2008 & $05 / 04$ & $01 / 05$ & $06 / 06$ & $26 / 06$ & $17 / 07$ & 09/08 & $11 / 09$ & $11 / 10$ \\
\hline ТТ-2009 & $13 / 04$ & $18 / 05$ & $21 / 06$ & $13 / 07$ & 03/08 & $27 / 08$ & $01 / 10$ & $05 / 11$ \\
\hline P-5683 & 06/04 & $07 / 05$ & 06/06 & $26 / 06$ & $18 / 07$ & $09 / 08$ & $11 / 09$ & $11 / 10$ \\
\hline Elçi & $18 / 04$ & $25 / 05$ & $29 / 06$ & $24 / 07$ & $15 / 08$ & 07/09 & $16 / 10$ & $20 / 11$ \\
\hline
\end{tabular}


Hasat işlemleri, parsellerin alt ve üst kısımlarından $0,5 \mathrm{~m}$, kenarlarından ise birer sıra kenar tesiri bırakılarak $4,8 \mathrm{~m}^{2}$ net alanda gerçekleştirilmiştir. Hasat zamanının belirlenmesinde bitkinin çiçeklenme ve tomurcuklanma durumu esas tutulmuş ve bitkiler \% 10-25 çiçeklenme gösterdiği dönemde $5 \mathrm{~cm}$ anız yüksekliği bırakılmak suretiyle biçim gerçekleştirilmiştir (Avcıoğlu, 1975). Her iki lokasyonda her yıl için yapılan hasat tarihleri Çizelge 3.'de sunulmuştur.

Denemede, ana sap uzunluğu $(\mathrm{cm})$, an sap çapı $(\mathrm{mm})$, ana sap sayısı (adet), yeşil ot verimi $(\mathrm{kg} / \mathrm{da})$, kuru madde oranı (\%) ve kuru madde verimi $(\mathrm{kg} / \mathrm{da})$ gibi karakterler incelenmiş ve Anonim (2001)'e göre değerlendirilmiştir. Çizelge 3,4 ve 5 'de verilen araştırma sonuçları, hazır paket program (TOTEM-STAT) kullanılarak ve 2 yıllık (2006-2007) ortalama değerler dikkate alınarak istatistik analizde değerlendirilmiştir (Açıkgöz vd., 1993). En Küçük Önemli Fark (LSD, \%5) değerleri her çizelgenin alt bölümünde verilmiştir.

\section{BULGULAR VE TARTISSMA}

Ana Sap Uzunluğu: Denemenin iki yıllık ortalama değerleri incelendiğinde, genotip ve lokasyon faktörleri istatistiksel olarak önemli bulunmuştur (Çizelge 4). Ana sap uzunlukları, Bornova lokasyonunda $73.36 \mathrm{~cm}$, Ödemiş'de ise $81.39 \mathrm{~cm}$ olarak saptanmıştır. Genotipler arasında en yüksek bitki boyu $81.50 \mathrm{~cm}$ ile TT-2008 çeşidinden elde edilirken, en kısa bitki boyları ise 73.97 $\mathrm{cm}$ ile Elçi ve $75.43 \mathrm{~cm}$ ile $\Pi-2009$ genotiplerinden kaydedilmiştir. Biçilerek hasat edilen, besleme ve sindirilme değeri bakımından yüksek kalitede bir ot üreten Yonca bitkisinde bitki boyu, verimle pozitif yönde ilişkilidir. Serin iklime adapte olan yoncalar, sıcak iklime adapte olanlara nazaran daha uzun bitki boyu oluşturmakta ve bitki boyu da genellikle ilk hasatta en yüksek değerde olup, daha sonraki biçimlerde giderek kısalmaktadır (Avcıoğlu 1983). Özellikle sıcak iklimlerde çabuk çiçeklenerek verimi düşük gerçekleşen çeşitler yerine, daha uzun sap oluşturabilen çeşitler tercih edilmektedir. Araştırmamızda kantitatif bir özellik olarak ele alınan bitki boyuna ait değerler, incelenen genotiplerinin uzun boylu gelişme gösterdiklerini ortaya koymuştur. Denememizden elde edilen değerler, Chamblee ve Warren (1990)'in denemelerinde inceledikleri yonca genotiplerinin bitki boylarından daha yüksek olarak bulunurken; Pecetti et. al. (1999); Şeker vd. (2003); Töngel ve Ayan (2010); Turan ve Çelen (2010); Yılmaz ve Albayrak (2011); Çınar ve Hatipoğlu (2012) ile Yüksel ve Balabanlı (2012)'nın bulguları ile uyum içersinde olduğu saptanmıştır.

Çizelge 4. Farklı lokasyonlarda yetiştirilen bazı yonca genotiplerinin ana sap uzunlukları $(\mathrm{cm})$

Table 4. Plant height of some alfalfa genotypes grown in different locations $(\mathrm{cm})$

\begin{tabular}{lccc}
\hline \multicolumn{1}{c}{ Genotipler } & Bornova & Ödemiş & Ortalama \\
\hline TT-2008 & 76.19 & 86.80 & $\mathbf{8 1 . 5 0}$ \\
TT-2009 & 72.55 & 78.30 & 75.43 \\
P-5683 & 73.88 & 83.32 & 78.60 \\
Elçi & 70.82 & 77.12 & 73.97 \\
Ort. & 73.36 & $\mathbf{8 1 . 3 9}$ & \\
\hline LSD (\%5) & Çeşit= 2.15 & Lokasyon= 1.52 & Çeşit x Lokasyon= Ö.D. \\
\hline
\end{tabular}

Ana Sap Çapı: Çizelge 5'de özetlenen ana sap çapı değerlerine uygulanan istatistiki analiz sonucu, çeşit ve lokasyon faktörleri istatistiksel olarak önemli bulunmuştur. Bornova lokasyonunda $3.03 \mathrm{~mm}$, Ödemiş' de ise $3.82 \mathrm{~mm}$ 'lik ana sap çapı değerleri elde edilmiştir. Genotipler arasında ana sap çapı bakımından en yüksek değer, aynı istatiksel grupta yeralan P-5683 (3.59 mm) ile $\Pi$-2008 (3.56 mm) genotiplerinden elde edilirken, en düşük ana sap kalınlığı değeri Elçi çeşidinde $3.21 \mathrm{~mm}$ ile kaydedilmiştir. Yoncalığın özellikle genç dönemlerinde ince ve yumuşak yapıya sahip olan ana sap, bitki olgunlaştıkça odunlaşmakta ve kalınlaşmaktadır (Soya vd. 1997). Bitkide sap kalınlığının artması hem verimi arttırmakta hem de bitkide yatma riskini azalmaktadır. Ana sap kalınlığına dair elde ettiğimiz bulgular, yapmış oldukları çalışmalarında ana sap çapının 2,24-4,00 mm arasında değiştiğini bildiren araştııııların sonuçları ile paralellik göstermektedir (Aka ve Avcıoğlu, 1999; Şeker vd., 2003; Töngel ve Ayan, 2010; Yılmaz ve Albayrak, 2011 ).

Çizelge 5. Farklı lokasyonlarda yetiştirilen bazı yonca genotiplerinin ana sap çapları (mm)

Table 5. Main stem diameter of some alfalfa genotypes grown in different locations ( $\mathrm{mm}$ )

\begin{tabular}{lccc}
\hline Genotipler & Bornova & Ödemiş & Ortalama \\
\hline TT-2008 & 3.12 & 3.99 & 3.56 \\
TT-2009 & 2.98 & 3.73 & 3.36 \\
P-5683 & 3.18 & 3.99 & $\mathbf{3 . 5 9}$ \\
Elçi & 2.84 & 3.57 & 3.21 \\
Ort. & 3.03 & $\mathbf{3 . 8 2}$ & \\
\hline LSD (\%5) & Çeşit= 0.08 & Lokasyon=0.06 & Çeşit x Lokasyon= Ö.D.
\end{tabular}


Ana Sap Sayısı: Denememizden elde edilen veriler, ana sap sayısı değerlerinin çeşit ve lokasyon faktörü bakımından istatistiksel anlamda farklıılık oluşturduğunu göstermektedir (Çizelge 6). Buna göre, Bornova lokasyonunda 13.49, Ödemiş'de ise 14.35 adet değerleri elde edilmiştir. Genotipler arasında istatiksel olarak farklı 2 grup meydana gelmiştir. En yüksek değerlerin elde edildiği ilk gruba 14.90 adet ile TT-2008 ve 14.47 adet ile $P$-5683 genotipleri, en düşük değerlerin alındığı son gruba ise Elçi (12.94 adet) TT2009 (13.39 adet) genotipleri dahil olmuşlardır. Denememizdeki ana sap sayısı değerleri, genotipler arasında dar sınırlar içerisinde değişmekte, buna karşın TT-2008 ve P-5683 genotiplerinin sürekli bir üstünlüğü izlenebilmektedir. Şeker vd. (2003); Kavut ve Soya (2004) ile Yılmaz ve Albayrak (2011)'ın bulgularıyla, araştırmamızda elde edilen ortalama ana sap sayıları benzerlik göstermektedir.

Çizelge 6. Farklı lokasyonlarda yetiştirilen bazı yonca genotiplerinin ana sap sayısı (adet)

Table 6. Number of main stems of some alfalfa genotypes grown in different locations (items)

\begin{tabular}{lccc}
\hline Genotipler & Bornova & Ödemiş & Ortalama \\
\hline TT-2008 & 14.22 & 15.57 & $\mathbf{1 4 . 9 0}$ \\
TT-2009 & 12.94 & 13.83 & 13.39 \\
P-5683 & 14.07 & 14.86 & 14.47 \\
Elçi & 12.74 & 13.14 & 12.94 \\
Ort. & 13.49 & $\mathbf{1 4 . 3 5}$ & \\
\hline LSD (\%5) & Çeşit=0.84 & Lokasyon=0.59 & Çeşit x Lokasyon= Ö.D. \\
\hline
\end{tabular}

Yeşil Ot Verimi: Yeşil ot verimlerindeki istatistiksel farklılığın, çeşit ve lokasyon faktörlerinde önemli olduğu saptanmış (Çizelge 7) ve Bornova lokasyonunda 10594 kg/da, Ödemiş'te ise 11041 kg/da'lık yeşil ot verimi değerleri elde edilmiştir. Genotiplere göre, en yüksek verim değeri, aynı istatistiksel grupta yeralan P-5683 (11885 kg/da) ile TT-2008 (11760 $\mathrm{kg} / \mathrm{da}$ ) genotiplerinden elde edilirken, en düşük verim değeri Elçi genotipinde 9515 kg/da ile kaydedilmiştir. Denememizin yürütüldüğü Bornova ve Ödemiş ovalarında yazları sıcak ve kurak, kışları ise ılık ve yağışlı olan Akdeniz iklimi egemen olduğundan, sıcak iklim yoncalarının ekolojik isteklerini gösteren genotiplerimiz, kış aylarını yarı dormant halde geçirmektedirler. Yoncanın yeşil ot veriminin ilk biçimde en yüksek değerde olduğunu belirten Gençkan ve Avcıoğlu (1978), verimin, yoncanın gelişme gücü, kök rezervlerinin değişimi ve özellikle toprak ve iklim koşullarına bağlı olarak sonraki biçimlerde düşüş gösterdiğini ifade etmektedirler. Denememizden elde edilen yeşil ot verimi ile ilgili değerlerin, Ayaz ve
Kızılşimşek (2010); Yılmaz ve Albayrak (2011); Yüksel ve Balabanlı (2012)'nın sonuçları ile benzer; Sharma ve Sharma (1993), Turan ve Çelen (2010); Çınar ve Hatipoğlu (2012)'nun bulgularından ise yüksek olduğu saptanmıştır. Elde edilen sonuçlarımız ile diğer araştırıcıların bulguları arasında görülen farklılıkların nedeninin, denemelerin yürütüldükleri ekolojilerin farklılığı ile uygulanan agronomik işlemlerdeki farklılıklardan kaynaklanabileceği kanaatine varılmaktadır.

Çizelge 7. Farklı lokasyonlarda yetiştirilen bazı yonca genotiplerinin yeşil ot verimleri $(\mathrm{kg} / \mathrm{da})$

Table 7. Green herbage yield s of some alfalfa genotypes grown in different locations ( $\mathrm{kg} / \mathrm{da}$ )

\begin{tabular}{lccc}
\hline Genotipler & Bornova & Ödemiş & Ortalama \\
\hline TT-2008 & 11285 & 12235 & 11760 \\
TT-2009 & 9997 & 10223 & 10110 \\
P-5683 & 11832 & 11938 & $\mathbf{1 1 8 8 5}$ \\
Elçi & 9260 & 9769 & 9515 \\
Ort. & 10594 & $\mathbf{1 1 0 4 1}$ & \\
\hline LSD (\%5) & Çeşit=427 & Lokasyon=302 & Çeşit x Lokasyon= Ö.D. \\
\hline
\end{tabular}

Kuru Madde Oranı: Denememizden elde edilen kuru madde oranı değerlerinde, çeşit ve lokasyon faktörleri ile bunların interaksiyonunun istatistiksel olarak önemli olduğu görülmektedir (Çizelge 8). En yüksek kuru madde oranı, \% 23.38 ile Ödemiş lokasyonunda yetiştirilen P-5683 çeşidinden elde edilmiş, aynı lokasyondaki T-2008 çeşidi de aynı yüksek değer grubu içerisinde yer almıştır. En düşük kuru madde oranı ise \% 21.25 ile Ödemiş lokasyonunda yetiştirilen Elçi çeşidinden elde edilirken, Bornova lokasyonundaki Elçi ve TT-2009 genotiplerinin de aynı düşük değer grubu içerisinde yer aldıkları saptanmıştır. Canlı hücrelerin kimyasal reaksiyonlar için mutlak suretle gereksinim duyduğu suyun oranı; hücre ve dokular, hatta sap ve yapraklar arasında bile önemli varyasyonlar göstermektedir.

Çizelge 8. Farklı lokasyonlarda yetiştirilen bazı yonca genotiplerinin kuru madde oranları (\%)

Table 8. Dry matter content s of some alfalfa genotypes grown in different locations (\%)

\begin{tabular}{lccc}
\hline Genotipler & Bornova & Ödemiş & Ortalama \\
\hline TT-2008 & 22.06 & 23.34 & 22.70 \\
TT-2009 & 21.69 & 22.09 & 21.89 \\
P-5683 & 21.98 & $\mathbf{2 3 . 3 8}$ & 22.68 \\
Elçi & 21.35 & 21.25 & 21.30 \\
Ort. & 21.77 & 22.52 & \\
\hline LSD (\%5) & Çeşit=0.42 & Lokasyon=0.30 & Çeşit x Lokasyon $=0.57$ \\
\hline
\end{tabular}


Büyüme ve gelişme olayları ile kalıtsal olarak kontrol edilen, ancak çevre koşullarından az etkilenen bir özellik olan kuru madde içeriğinin (Bulgurlu ve Ergül, 1978) azalması, bitkilerdeki su oranının yüksek olmasıyla açıklanabilmektedir. Daha önceki çalışmalar ile karşılaştıııldığında; kuru madde oranına ait bulgularımızın pek çok araştıııının bildirdiği sınırlar içinde kaldığı (Aka ve Avcıoğlu, 1999; Kavut ve Soya, 2004) görülmektedir.

Kuru Madde Verimi: Çizelge 9'dan da izlenebileceği üzere kuru madde verimi değerlerine uygulanan istatistiki analiz sonucunda, çeşit ve lokasyon faktörlerinin istatistiksel anlamda farklılık yarattığı görülmektedir. Bornova lokasyonunda 2314 $\mathrm{kg} / \mathrm{da}$, Ödemiş'de ise $2505 \mathrm{~kg} / \mathrm{da}$ 'lık kuru madde verimleri elde edilmiştir. Genotipler arasında kuru madde verimi bakımından en yüksek değerler, aynı istatistiksel grupta yeralan P-5683 $(2710 \mathrm{~kg} / \mathrm{da})$ ile TT$2008(2678 \mathrm{~kg} / \mathrm{da})$ genotiplerinden elde edilirken, en düşük verim değeri Elçi çeşidinde $2031 \mathrm{~kg} / \mathrm{da}$ ile kaydedilmiştir. Yonca genotiplerinin kuru madde verimine ilişkin elde ettiğimiz sonuçların, Ayaz ve Kızılşimşek (2010)'in verileriyle uyumlu, buna karşın Loges und Taube (1999); Kavut ve Soya (2004); Turan ve Çelen (2010); Çınar ve Hatipoğlu (2012)'nun bulgularından ise yüksek olduğu saptanmıştır. Bu farklılık denemelerin yürütüldüğü yıllara ilişkin iklim ve toprak faktörlerinin ve denemelerde kullanılan genotiplerin

\section{KAYNAKLAR}

Açıkgöz, N., 1993. Tarımda Araştırma ve Deneme Mteodları (III.Basım), Ege Üniversitesi Ziraat Fakültesi Yayınları No:478, Ege Üniversitesi Ziraat Fakültesi Ofset Atelyesi, Bornova-İzmir, 202s.

Aka, M.A. ve Avcıoğlu, R., 1999. Selçuk Koşullarında 7 Farklı Yonca Çeşidinin Verim ve Diğer Bazı Verim Özellikleri Üzerinde Araştırmalar, E.Ü. Fen Bil. Enst. Tarla Bitkileri Anabilim Dalı, Bornova, İzmir, 33s (Yayınlanmamış Yüksek Lisans Tezi).

Alçiçek, A., Kılıç, A., Ayhan, V. ve Özdoğan, M., 2010. Türkiye’de Kaba Yem Üretim ve Sorunları, Bildiriler Kitabı-2, Türkiye Ziraat mühendisleri Odası VII. Teknik Kongresi, 11-15 Ocak 2010, Ankara, s: 1071-1080.

Anonim, 2001, Tarımsal Değerleri Ölçme Denemeleri Teknik Talimatı, T.C. Tarim Ve Köyişleri Bakanliği Tohum Tescil ve Sertifikasyon Merkezi 36s.

Anonim, 2006a. Bornova Bölge Meteoroloji İstasyonu, Bornovaİzmir.

Anonim, 2006b. Ödemiş Bölge Meteoroloji İstasyonu, Ödemiş-İzmir.

Avcıŏglu, R., 1975. Yonca'da Biçim Zamanı ve Yüksekliğinin Verim ve Diğer Bazı Karakterlere Etkisi Üzerinde Araştırmalar, Ege Üniversitesi Ziraat Fakültesi, Bornova-İzmir, 179s (Basılmamiş Doktora Tezi). farklı genotipik özelliklere sahip olmasıyla açıklanabilmektedir.

Çizelge 9. Farklı Lokasyonlarda Yetiştirilen Yonca Genotiplerinin Kuru Madde Verimleri $(\mathrm{kg} / \mathrm{da})$

Table 9. Dry matter yields of some alfalfa genotypes grown in different locations $(\mathrm{kg} / \mathrm{da})$

\begin{tabular}{lccc}
\hline Genotipler & Bornova & Ödemiş & Ortalama \\
\hline TT-2008 & 2493 & 2862 & 2678 \\
TT-2009 & 2176 & 2261 & 2219 \\
P-5683 & 2601 & 2818 & $\mathbf{2 7 1 0}$ \\
Elçi & 1984 & 2078 & 2031 \\
Ort. & 2314 & $\mathbf{2 5 0 5}$ & \\
\hline
\end{tabular}

LSD (\%5)

Çeşit $=120 \quad$ Lokasyon $=85 \quad$ Çeşit $\times$ Lokasyon $=$ Ö.D.

\section{SONUÇLAR}

Denemede ele alınan yonca genotiplerinin, Bornova lokasyonuna oranla daha hafif bir toprak tekstürünü temsil eden Ödemiş lokasyonunda daha yüksek performans gösterdikleri kaydedilmiştir. Genotipler içerisinde de özellikle TT-2008 ve P-5683 genotiplerinden, incelenen bir çok verim karakteri bakımından, diğer genotiplere oranla daha yüksek değerlerin kaydedildiği ve Akdeniz iklim kuşağına rahatlıkla önerilebilecekleri saptanmıştır.

Avcıoğlu, R., 1983. Yembitkileri Yetiştirme, Ege Üniversitesi Ziraat Fakültesi Yayınları No:83-II, Bornova-İzmir, 92s.

Ayaz, H. ve Kızılşimşek, M., 2010. Elçi Yoncasında Farklı Biçim Zamanlarında Tarımsal ve Fizyolojik Özelliklerin Gün İçersindeki Değişimi. Kahramanmaraş Üniversitesi Fen Bilimleri Enst. (Basılmamış Yüksek Lisans Tezi), Kahramanmaraş, 35s.

Bulgurlu, Ş. ve Ergül, M., 1978. Yemlerin Fiziksel, Kimyasal ve Biyolojik Analiz Metodları, Ege Üniversitesi Ziraat Fakültesi Yayınları No:127, Ege Üniversitesi Matbaası, Bornova-İzmir, s: 58-76.

Chamblee, D.S. and Warren, Jr.R.D., 1990. Movement of Rhizobia Between Alfalfa Plants Agronomy J 82 :p : 283-286.

Çınar, S. ve Hatipoğlu, R., 2012. Çukurova Taban Koşullarında Bazı Çokyıllık Sicak Mevsim Buğdaygil Yembitkilerinin Yonca (Medicago sativa L.) İle Uygun Karışımlarının Belirlenmesi. Çukurova Üniversiyesi Fen Bilimleri Enst. (Basılmamış Doktora Tezi), Adana, 151s

Gençkan, M.S. ve Avcioğlu, R. 1978. Değişik Yüksekliklerde Uygulanan Biçim Sıralarının Yoncanın Bazı Verim Özelliklerine Etkisi, Ege Üniversitesi Ziraat Fakültesi Dergisi, Bornova-İzmir, Cilt:15, s:1-13.

Kavut, Y.T. ve Soya, H., 2004. Bazı Yeni Yonca (Medicago sativa L.) Çeşitlerinin Bornova Koşullarındaki Performansları Üzerine Bir 
Araștırma, Ege Üniversitesi Fen Bilimleri Enstitüsü Tarla Bitkileri Anabilim Dalı (Basılmamış Yüksek Lisans Tezi), $61 \mathrm{~s}$.

Loges, R. and Taube, F., 1999. Ertrag und Futterqualität von Rotklee und Luzerne als Reinsaat sowie im Gemenge mit Gräsern. [Yield and forage quality of red clover and alfalfa in pure stand and in mixture with grass.] In: Hoffmann, Heide and Müller, Susann (Eds.) Vom Rand zur Mitte: Beiträge zur 5. Wissenschaftstagung zum Ökologischen Landbau, Verlag Dr. Köster, Berlin, pp. 501-504.

Pecetti, L., Piano, E. and Romani, M., 1999. Variation in Morphophysiological Traits of Exotic Lucerne Germplam in Northern Italy, Proc. XIII. Eucarpia Medicago spp. Group Meeting Perugia, Italy, 13-16 September 1999, p: 44-51.

Sharma, P.K. and Sharma, B.L., 1993. Response of Lucerne (Medicago sativa) Varieties To Seed Rate And Effect of Mixing of Chinese Cabbage (Brassica chinensis) Seed With Lucerne Seed on Green Forage Yield Indian Agronn J 40 (1): p:162-163.

Soya, H., Avcioğlu, R. ve Geren, H., 1997. Yembitkileri, Hasad Yayıncılık Ltd. Şti. PK. 212, Kadiköy-İstanbul, 223s.

Șeker, H., Tahtacioglu, L. ve Aygün, C. 2003. Dogu Anadolu yoncasından elde edilen hatların Kayseri ve Bilensoy-80 çeşitleriyle karşılaştırılmalı genel mahsül büyüme oranları ve bazı morfolojik özellikler. Atatürk Üniv. Ziraat Fak. Derg. 34(4): 303307, Erzurum.
Töngel, M.Ö. ve Ayan, İ., 2010. Nutritional Contenst and Yield Performances of Lucerne (Medicago sativa L.) Cultivars in Southern Black Sea Shores. Department of Agronomy, Faculty of Agriculture, University of Ondokuz May1s, 55139, Kurupelit, Samsun, Turkey. (15), p:2067-2073.

TUIK, 2011, tuik.gov.tr

Turan, N. ve Celen, A.E., 2010. Bazı Yonca (Medicago sativa L.) Çeşitlerinin Farklı Ekim Zamanlarında Verim ve Verim Unsurlarının Belirlenmesi Üzerinde Bir Araștırma. Van Yüzüncüyıl Üniversitesi Fen Bilimleri Enst., (Basılmamış Doktora Tezi),Van, 103s

Tükel T. ve R. Hatipoğlu. 1994. Çukurova Bölgesinde Bulunan Doğal Domuz Ayrığı Bitkisinin Morfolojik Biyolojik ve Tarımsal Karakterleri Üzerinde Araştırmalar;Tarla Bitkileri Kongresi.Çayır Mera ve Yembitkileri Bildirileri. Cilt:3. 25-29 Nisan. İzmir. s:4447.

Yılmaz, M. ve Albayrak, S., 2011. Isparta Ekolojik koşullarında Bazı Yonca (Medicago sativa L.) Çeşitlerinin Ot Verim ve Kalitelerinin Belirlenmesi. Süleyman Demirel Üniversitesi Fen Bilimleri Enst. (Basılmamış Yüksek Lisans Tezi), Isparta, 43s.

Yüksel, O. ve Balabanlı, C., 2012. Suni Çayır Tesisinde Yonca (Medicago sativa L.) İle Karışıma Girebilecek Buğdaygil Yembitkilerinin ve En Uygun Karışım Oranlarının Belirlenmesi. (Basılmamış Doktora Tezi), Isparta, 117s. 